\title{
Implementation of Confirmation of Methods in Measurement Equipment \\ Calibration as a Normalized Strategy to Ensure the Quality of \\ Measurements Made in the Construction, Repair, and Modernization of \\ Ships and Naval Artifacts in COTECMAR
}

Implementación de la confirmación de métodos en la calibración de equipos de medición como estrategia

normalizada para asegurar la calidad de las mediciones realizadas en la construcción, reparación y modernización de buques y artefactos navales en COTECMAR

Ronald Yesid Argote Guzmán ${ }^{1}$

\begin{abstract}
The naval, maritime and riverine industry is one of the sectors, which has greater contribution to the world economy, hence, quality assurance is one of the main priorities in all maritime activities, especially the ones related to ship building. The monitoring of different variables that allows good performance of a ship involves assessing equipment in order to assure data taking with greater precision and accuracy; this is where metrology takes place as a science for studying inherent problems to measurement data collection, focusing on equipment calibration. The grade of uncertainty produced by data taking procedures of each equipment on board of ship depend on techniques and results control specifications, which are known as Methods Confirmation. The metrology laboratory at COTECMAR applied this method to guarantee quality by estimating validity and reliability of the obtained results through different measuring equipment related to ship construction and repairing.
\end{abstract}

Key words: Ship, calibration, metrology, Methods Confirmation, quality assurance

\section{Resumen}

La industria naval, marítima y fluvial es uno de los sectores que tiene mayor contribución a la economía mundial, por ende, el aseguramiento de la calidad es una de las prioridades en las actividades marítimas, especialmente en la construcción de embarcaciones. El monitoreo de las diferentes variables que permiten el buen desempeńo de un buque implica la comprobación de equipos para garantizar la toma de datos con mayor precisión y exactitud posible, es aquí donde la metrología tiene lugar como ciencia por estudiar los problemas inherentes a la toma de datos de medida, enfocándose una de sus ramas a la calibración de equipos. El grado de incertidumbre o sesgo generado por la toma de medidas de cada uno de los equipos a bordo de una embarcación dependen de las técnicas y especificaciones de control de resultados, las cuales se conocen como Confirmación de Métodos. En el laboratorio de metrología de COTECMAR se implementa dicha metodología para garantizar el aseguramiento de la calidad por medio de la evaluación de validez y veracidad de los resultados obtenidos a través de los distintos equipos de medición involucrados en la construcción y reparación de buques.

Palabras claves: Embarcación, calibración, metrología, Confirmación de Métodos, aseguramiento de la calidad

Date Received: May 31th, 2014 - Fecha de recepción: 31 de mayo de 2014

Date Accepted: July 18th, 2014 - Fecha de aceptación: 18 de julio de 2014 


\section{Introduction}

The importance the naval, maritime, and riverine industry has gained over time is mainly due to the set of activities, processes, and results it has contributed to the development of the economy and industry at the global level. The aforementioned involves the risks to which human lives are exposed when aboard a vessel operating in the different waters of the world.

After Titanic's disaster in 1912, the safety of human life at sea has become a priority for all the countries in the world; for this reason, the shipyard industry must respond more effectively. As a result to this sad moment in history, the International Convention for the Safety of Life at Sea (SOLAS) was approved in 1914, which in its version in effect from 01 November 1974 sanctioned during the International Conference on Safety of Human Life at Sea, convened by the International Maritime Organization (IMO), and which went into effect on 25 May 1980, has as main objective to establish guidelines from every point of view to minimize the risks to which human life is exposed at sea. Taking as example chapter XI of this treaty, regulation 2 stipulates that bulk carriers and oil tankers will be object of an improved inspection program in conformity with the guidelines approved by the IMO Assembly in 1993 through resolution A.744(18) ${ }^{1}$. The guidelines on the improved inspections program have been elaborated by the IMO as a consequence of the high number of claims occurring in recent years and from the growing concern for the aging of the global merchant fleet ${ }^{2}$. The guidelines pay special attention to corrosion. The coatings and the corrosion prevention systems on the tanks must be subjected to extensive testing and plate thickness measurements must also be made. Procedures are described to certify the companies that conduct thickness measurements of hull structures; procedures are recommended for thickness measurements and thorough

\footnotetext{
http://www.inocar.mil.ec/web/images/lotaip/2015/literal_a/ base_legal/A._Convenio_internacional_solas_1974.pdf. Instituto Oceanográfico de la Armada INOCAR. Ecuador. 2015-05-31.

2 http://www.inocar.mil.ec/web/images/lotaip/2015/literal_a/ base_legal/A._Convenio_internacional_solas_1974.pdf. Instituto Oceanográfico de la Armada INOCAR. Ecuador. 2015-05-31.
}

recognition; and orientations are given on how to elaborate the documentation required. With the aforementioned, it can be seen that the measurements made of the different structures, parts, and/or equipment on a vessel are quite important, given that their results are a critical variable within the quality assurance of the product obtained and which is directly related to human risks on board a ship.

Enhancement of economic and social issues in Colombia is highly linked to naval, maritime and riverine development along with the safety of human life at sea; hence, Legislation 8 of 1980 was sanctioned, which considered the guidelines of 1974 and 1978 protocols, the latter is no longer in effect because of the 1988 International SOLAS Protocol pending Congressional approval for its adoption $^{3}$.

By mid 1998 the Colombian Navy sought the necessary resources to bring to life the shipyard industry in Colombia and created what is today the Science and Technology Corporation for the Development of the Naval, Maritime, and Riverine Industry, COTECMAR, founded in 2000 by the Ministry of Defense, Universidad Nacional de Colombia, Corporation Universitaria Tecnológica de Bolívar, and Escuela Colombiana de Ingeniería 'Julio Garavito'.

COTECMAR has as mission statement "to lead in the scientific and technological development National Navy, satisfying the needs for support and evolution of its fleet, promoting the sustainable growth of the nation's naval, maritime, and riverine industry"s. Within this scientific and technological development, COTECMAR, has generated and implemented a series of strategies that permit assuring the quality of its products, besides obeying with all the applicable international and national laws. Among these strategies, there is that of keeping a metrology laboratory in charge of calibrating

https://www.dimar.mil.co/content/convenio-internacionalsobre-la-seguridad-de-la-vida-humana-en-el-mar. Dirección General Marítima, Autoridad Marítima Colombiana. 2015-05-31. 4 http://www.semana.com/especiales/articulo/potencianaval/47869-3. Revista Semana. 2001-11-05. http://www.cotecmar.com/conozcanos.html. Portal COTECMAR. 2015-05-31. 
the Corporation's measuring equipment, which makes sure the results of measurements made with said equipment are reliable and true.

The reliability and veracity mentioned are only obtained by implementing adequate statistical and mathematical techniques to calibration processes conducted in the laboratory. One of these techniques has to do with Confirmation of Methods, which seeks to ensure that the results of the measurements during routine analyses are sufficiently close to the real value (unknown) of the analyte content in the sample ${ }^{6}$. The laboratory selects the calibration methods according to current regulations (whenever pertinent), according to the requirements of the final user (client).

The purpose of this article was to show the results reached by implementing the confirmation of methods during the calibration process of equipment in the metrology laboratory at COTECMAR, as strategy for quality assurance of the results of measurements in terms of reliability and veracity.

\section{Measurement and calibration of measuring equipment}

The activity of a measurement process unavoidably involves technical, administrative, statistical, instrumental, and personnel aspects, establishing each of these within their own control parameter that ensure accurate data obtained during said process. An ideal measurement process will always provide "true" measurements, which implies having statistical properties of zero variance, zero errors and, consequently, zero probability of wrong decisions. Unfortunately, these types of measurement processes do not exist, which allows the existence of systems or measurement processes according to the precision required, costs, ease of use, etc. A measurement process has a vast diversity of considerations or points of its own interpretation; said understanding of the process varies according

6 https://fernandoveyretou.files.wordpress.com/2011/06/validacion-y-confirmacion-de-metodos26.pdf. Ingeniería en Calidad Fernando Veyretou. Temas de Calidad. Laboratorio. 2011-06-10. to the area of application where it will be carried out. For example, metrology experts will use VIM3 to interpret and apply the definitions to said process; engineers in industry will base themselves on the definitions and terms most commonly used in management systems, and mathematicians will interpret said process according to established limits and boundaries?

According to the International Metrology Vocabulary, in its third translation (VIM3), 'measurement' is defined as:

"A process that consists in experimentally obtaining one or several values that may be reasonably attributed to a magnitude".

Notes:

1. Measurements do not apply to qualitative properties.

2. A measurement supposes a comparison of magnitudes or the count of entities.

3. A measurement supposes a description of the magnitude compatible with the foreseen use of a measurement result, a measurement procedure, and a measurement system calibrated according to a specified measurement procedure, including the measurement conditions. ${ }^{8}$

Continuing with the scheme of the measurement process, Fig. 1 illustrates analogies of said process seen by.

If the process is analyzed by stages, we may establish that in "A" and " $C$ " there are no problems in identifying and understanding said processes, given that in these stages the elements under study are clearly identified, including the analogies can be carried out without problem; unfortunately, in stage "B" a problem emerges due to causes like:

- Level of precision required in $\mathrm{C}$, which results in the complexity of the process in $\mathrm{B}$,

- Recognition and validation of stage $B$,

- Integration and separation of critical instruments,

\footnotetext{
http://www.metas.com.mx/guiametas/La-Guia-MetAs-07-09proceso-de-medicion.pdf. MetAs \& Metrólogos Asociados. La Guía MetAs. Septiembre de 2007.

8 International Metrology Vocabulary. VIM-3rd edition (2012).
} 
Fig. 1.

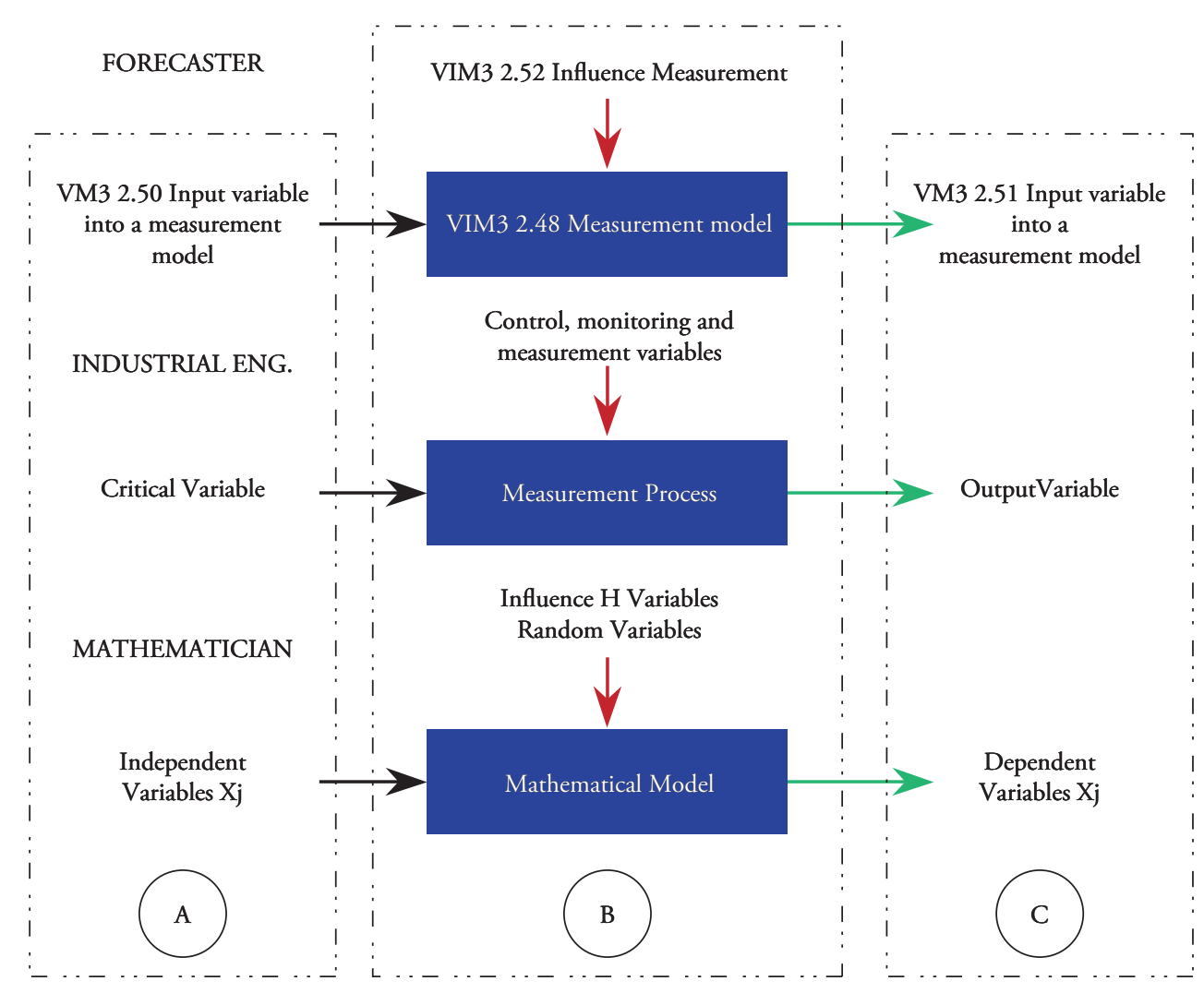

Source: MetAs \& Metrólogos Asociados.

magnitudes, and elements of influence,

- Required variability of the process,

- Among others.

This demonstrates that stage $\mathrm{B}$ is an area of transformation, which should be analyzed and studied in greater depth'. From the concept of "measurement", the calibration concept is generated that according to VIM3 is:

"Operation that under specified conditions establishes, in a first stage, a relationship among the values and their associated measurement uncertainties obtained from the measurement patterns, and the corresponding indications with their associated uncertainties and, in a second stage, utilizes this information to establish a relationship that permits obtaining a

\footnotetext{
http://www.metas.com.mx/guiametas/La-Guia-MetAs-07-09proceso-de-medicion.pdf. MetAs \& Metrólogos Asociados. La Guía MetAs. Septiembre de 2007.
}

measurement result from an indication".

Notes:

1. A calibration may be expressed through a statement, a calibration function, a calibration diagram, a calibration curve, or a calibration table. In some cases, it may consist of an additive or multiplicative correction of the indication with its corresponding uncertainty.

2. It is convenient not to confuse calibration with the adjustment of a measuring system, often incorrectly called "self-calibration", or with a verification of the calibration.

3. Frequently, it is interpreted that only the first stage of this definition corresponds to calibration. ${ }^{10}$

Then, it may be stated that calibration is the comparison of a standard of measurement, or equipment, with a standard or equipment of greater

10 International Metrology Vocabulary. VIM-3rd edition (2012). 
precision, to detect and quantify inaccuracies and report or eliminate them through an adjustment. Hence, within the measurement process, calibration is the most important quality control activity, given that it establishes the relationship of the value measured by equipment with a real conventional value, giving the measurement validity and traceability. The following image shows that previously mentioned, a digital calliper gauge is calibrated by using a set of pattern blocks with greater precision than that of the equipment.

Fig. 2.

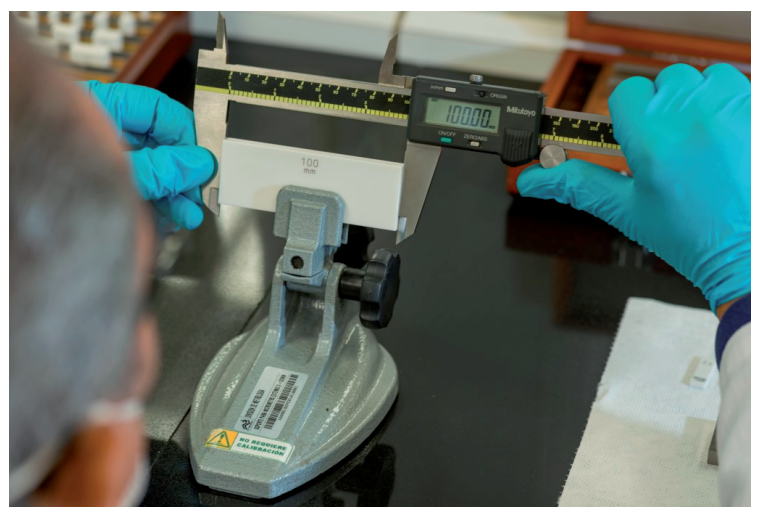

When using measuring equipment continuously, precision and measurement precision vary gradually due to wear of its parts or due to interference caused by the accumulation of dust or dirt, among other causes or reasons, which is why it is necessary to validate them through calibration and correct them if necessary. All equipment must be calibrated by following the operating conditions, pursuant to procedures based on the specific instructions of the equipment's operation manual, as well as on the general guidelines provided by the normalized or non-normalized methods.

During the execution of the calibration program, different types of calibrations take place, whose complexity and application may vary in function of the circumstances and objectives established. However, it is important for the calibrations to consider the following aspects:

- Traceability of the standards or reference materials;

- Procedures or methods established and validated or confirmed;
- Programming; and

- Documentation of the results.

\section{Analysis strategy: confirmation of methods}

The NTC-ISO/IEC 17025 standard (version 2005), applied in COTECMAR's metrology laboratory and through which it obtained its accreditation, in numerals 5.4.2 and 5.4.5.2, respectively, states:

"The laboratory must use the test or calibration methods, including sampling methods, which satisfy the needs of the client and which are appropriate for the tests or calibrations performed. Preferably, methods published as international, regional, or national norms should be used ..."

\section{"The laboratory must validate the no-normalized methods, the methods it designs or develops, the normalized methods used beyond the foreseen reach, as well as extensions and modifications of the normalized methods, to confirm that the methods are suitable for the purpose sought. The validation must be as broad as necessary to satisfy the needs of the given type of application or field of application..."}

The confirmation of methods is the validation of normalized methods issued by international normalization organizations (e.g., ISO), regional organizations (European norms, EN, or MERCOSUR, NM), or national organizations like ICONTEC, etc. Methods issued by internationally recognized organizations like EPA, AOAC, etc., are also considered 'normalized' methods. The results of this confirmation show us the veracity and accuracy of the method and of the results of the measurements

In the metrology laboratory at COTECMAR this strategy is adequate for the methods used in the calibration process and its calculation and analysis basis of the results is founded on the NTC 35292 standard of 1999, identical to the ISO 5725-3 standard of 1994. 


\section{Methodology}

The activity was basically carried out in four phases:

\section{Phase 1: Election of the measurand}

COTECMAR's metrology laboratory calibrates measuring equipment in two main magnitudes, which are dimensional magnitude and pressure magnitude; within the reach of its management system, the equipment object of this confirmation of methods were chosen bearing in mind the following:

- That they are within the reach of laboratory accreditation.

- Their state of preservation; physical and operating conditions.

- Result of prior calibrations (if equipment is not new).

\section{Phase 2: Selection of analysis method}

The methodology selected to obtain and analyze the results of the confirmation of the method in the graphic consistency technique called "Mandel's $\mathrm{h}$ and $\mathrm{k}$ statistics", documented in the NTC 35292 standard of 1999, requisite 7.3.1. It is worth mentioning that this requisite is segregated in the content of the norm in other applicable requirements, which is why it is recommended to revise the text.

\section{Phase 3: Calibration of the measurand}

Execution of the standardized calibration process the laboratory performs for the selected measurement equipment, bearing in mind the laboratory's internal guidelines (calibration instructions and applicable technical norms) and the confirmation of the method regarding repetition conditions of the calibrations and order of calibration stipulated in the NTC 3529-2 standard of 1999, requisite 7.3.1.

Phase 4: Obtaining and analyzing the results

The results of calibrations performed were analyzed according to that stipulated in the NTC 35292 standard of 1999, requisite 7.3.1. Upon ending the activity, we must obtain the lowest of the uncertainties reported for the calibrations made for each measurand; this uncertainty is denominated Capacity for Measurement and Calibration (CMC).

Note: for greater reference on the CMC, visit: www.onac.org.co.

\section{Results}

\section{Phase 1: Election of the measurand}

Owing to the vast scope of the laboratory for confirmation methods, a measurand was selected within the accreditation limits of COTECMAR's metrology laboratory. to show its whole development. The measurand selected is the Calliper gauge in its different presentations according to the laboratory's capacity, thus:

Table 1.

\begin{tabular}{|c|c|c|c|c|}
\hline Magnitude & Range of measurement & Instrument to calibrate & Pattern equipment used & Normative document \\
\hline Length & $0-150 \mathrm{~mm}$ & $\begin{array}{l}\text { Calliper calibrator } \\
\text { Type: } \mathrm{M} \text { and } \mathrm{CM} \\
\text { Division of scale: } 0.01 \mathrm{~mm}\end{array}$ & $\begin{array}{l}\text { Pattern block set Class } \\
1 \text { and } 2\end{array}$ & $\begin{array}{l}\text { JIS B } 7507 \text { - } 1993 \\
\text { (Numeral 6.1, Table 1 - } \\
\text { Numeral 12, Table 9) }\end{array}$ \\
\hline Length & $0-300 \mathrm{~mm}$ & $\begin{array}{l}\text { Calliper calibrator } \\
\text { Type: } \mathrm{M} \text { and CM } \\
\text { Division of scale: } 0.01 \mathrm{~mm}\end{array}$ & $\begin{array}{l}\text { Pattern block set Class } \\
1 \text { and } 2\end{array}$ & $\begin{array}{l}\text { JIS B } 7507-1993 \\
\text { (Numeral 6.1, Table 1- } \\
\text { Numeral 12, Table 9) } \\
\end{array}$ \\
\hline Length & $0-500 \mathrm{~mm}$ & $\begin{array}{l}\text { Calliper calibrator } \\
\text { Type: } \mathrm{M} \text { and } \mathrm{CM} \\
\text { Division of scale: } 0.01 \mathrm{~mm}\end{array}$ & $\begin{array}{l}\text { Pattern block set Class } \\
1 \text { and } 2\end{array}$ & $\begin{array}{l}\text { JIS B } 7507 \text { - } 1993 \\
\text { (Numeral 6.1, Table 1 - } \\
\text { Numeral 12, Table 9) }\end{array}$ \\
\hline Length & $0-900 \mathrm{~mm}$ & $\begin{array}{l}\text { Calliper calibrator } \\
\text { Type: } \mathrm{M} \text { and } \mathrm{CM} \\
\text { Division of scale: } 0.02 \mathrm{~mm}\end{array}$ & $\begin{array}{l}\text { Pattern block set Class } \\
1 \text { and } 2\end{array}$ & $\begin{array}{l}\text { JIS B } 7507-1993 \\
\text { (Numeral 6.1, Table 1- } \\
\text { Numeral 12, Table 9) }\end{array}$ \\
\hline
\end{tabular}


Fig. 3. Digital calliper gauge.

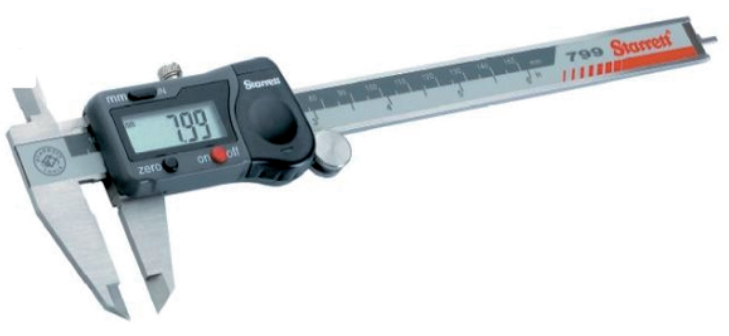

Phase 2: Selection of analysis method

The methodology selected to obtain and analyze the results of the confirmation of the method is the graphic consistency technique called "Mandel's $h$ and $k$ statistics", documented in the 1999 NTC 3529-2 standard, requisite 7.3.1. This methodology was chosen because adjusted to the laboratory capacities and, mainly, because it belongs to a nationally accepted reference norm.

\section{Phase 3: Calibration of the measurand}

For each of the equipment mentioned in item 5.1, respective calibrations were carried out according to COTECMAR's internal calibration instructions, which corresponds to each of them. In this case, the calliper corresponds to internal instruction code $\mathrm{N}^{\circ}$ I-COPSER-001.

\section{Phase 4: Obtaining and analyzing the results}

The graphic consistency technique was used to analyze the results; this uses two measurements called Mandel's $h$ and $k$. This technique is described in numeral 7.3.1 of the NTC 3529-2:1999 standard. The values of Mandel's $h$ and $k$ measurements were obtained from Table 7, in the NTC 35292:1999 standard, with 95\% confidence level $(5 \%$ significance), for three operators and three repetitions per operator.

The following show the results obtained for each measurement interval supported by each pattern instrument used, as shown in numeral 4.1 of this report.

Table 2. Measurement range up to $150 \mathrm{~mm}$, division of scale $0.01 \mathrm{~mm}$.

\begin{tabular}{|c|c|c|c|c|c|c|}
\hline \multirow{2}{*}{ Operator } & \multicolumn{6}{|c|}{ Indications (mm) } \\
\hline & $\mathbf{0}$ & 30 & 70 & 100 & 120 & 150 \\
\hline \multirow{3}{*}{$\begin{array}{l}\text { Delwin } \\
\text { Velandia }\end{array}$} & 0.000 & 30.000 & 69.998 & 99.998 & 119.994 & 149.994 \\
\hline & 0.000 & 30.004 & 69.996 & 100.000 & 119.996 & 150.002 \\
\hline & 0.000 & 29.998 & 70.002 & 99.996 & 119.998 & 150.000 \\
\hline Mean & 0.000 & 30.0007 & 69.9987 & 99.9980 & 119.9960 & 149.9987 \\
\hline Deviation & 0.000 & 0.003 & 0.003 & 0.002 & 0.002 & 0.004 \\
\hline $\mathbf{h}$ & 0.00000 & 0.00006 & 0.00000 & 0.00000 & 0.00000 & -0.00001 \\
\hline $\mathbf{k}$ & 0.00000 & 1.00000 & 1.00000 & 0.68825 & 1.50000 & 1.14018 \\
\hline \multirow{3}{*}{$\begin{array}{l}\text { Majer } \\
\text { Atequera }\end{array}$} & 0.000 & 29.998 & 69.998 & 99.996 & 119.998 & 149.996 \\
\hline & 0.000 & 29.998 & 69.998 & 100.002 & 119.996 & 150.004 \\
\hline & 0.000 & 29.996 & 70.000 & 99.994 & 119.996 & 150.002 \\
\hline Mean & 0.000 & 29.9973 & 69.9987 & 99.9973 & 119.9967 & 150.0007 \\
\hline Deviation & 0.000 & 0.001 & 0.001 & 0.004 & 0.001 & 0.004 \\
\hline $\mathbf{h}$ & 0.00000 & -0.00005 & 0.00000 & 0.00000 & 0.00000 & 0.00000 \\
\hline $\mathbf{k}$ & 0.00000 & 0.37796 & 0.37796 & 1.43270 & 0.86603 & 1.14018 \\
\hline \multirow{3}{*}{$\begin{array}{l}\text { Ronald } \\
\text { Argote }\end{array}$} & 0.000 & 30.000 & 69.996 & 99.998 & 119.996 & 149.998 \\
\hline & 0.000 & 30.002 & 69.998 & 100.000 & 119.996 & 150.002 \\
\hline & 0.000 & 29.994 & 70.004 & 99.996 & 119.996 & 150.002 \\
\hline Mean & 0.000 & 29.9987 & 69.9993 & 99.9980 & 119.9960 & 150.0007 \\
\hline Deviation & 0.000 & 0.004 & 0.004 & 0.002 & 0.000 & 0.002 \\
\hline $\mathbf{h}$ & 0.00000 & -0.00001 & 0.0001 & 0.00000 & 0.00000 & 0.00000 \\
\hline $\mathbf{k}$ & 0.00000 & 1.36277 & 1.36277 & 0.68825 & 0.00000 & 0.63246 \\
\hline
\end{tabular}


Fig. 4. Graph of h.

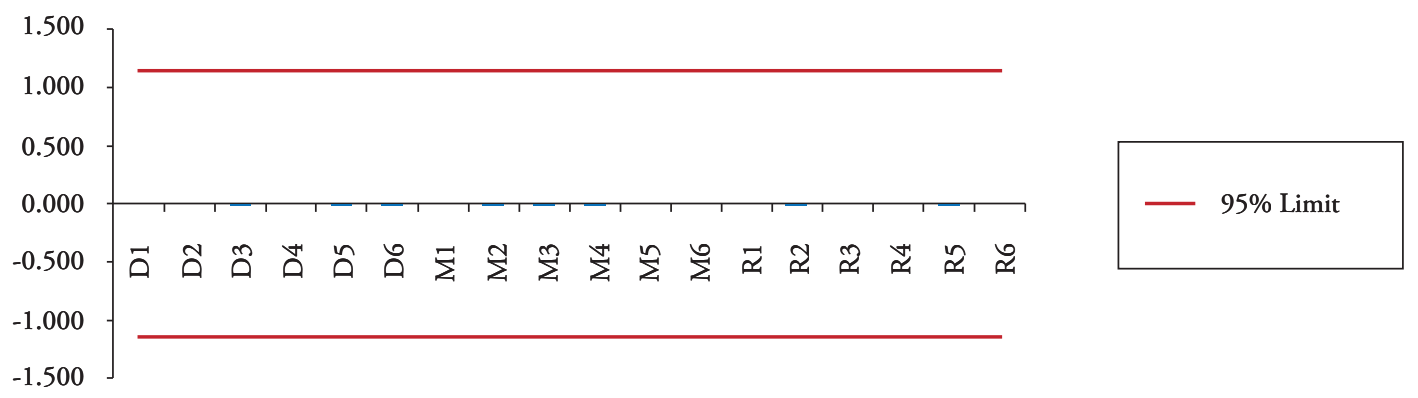

Fig. 5. Graph of k.

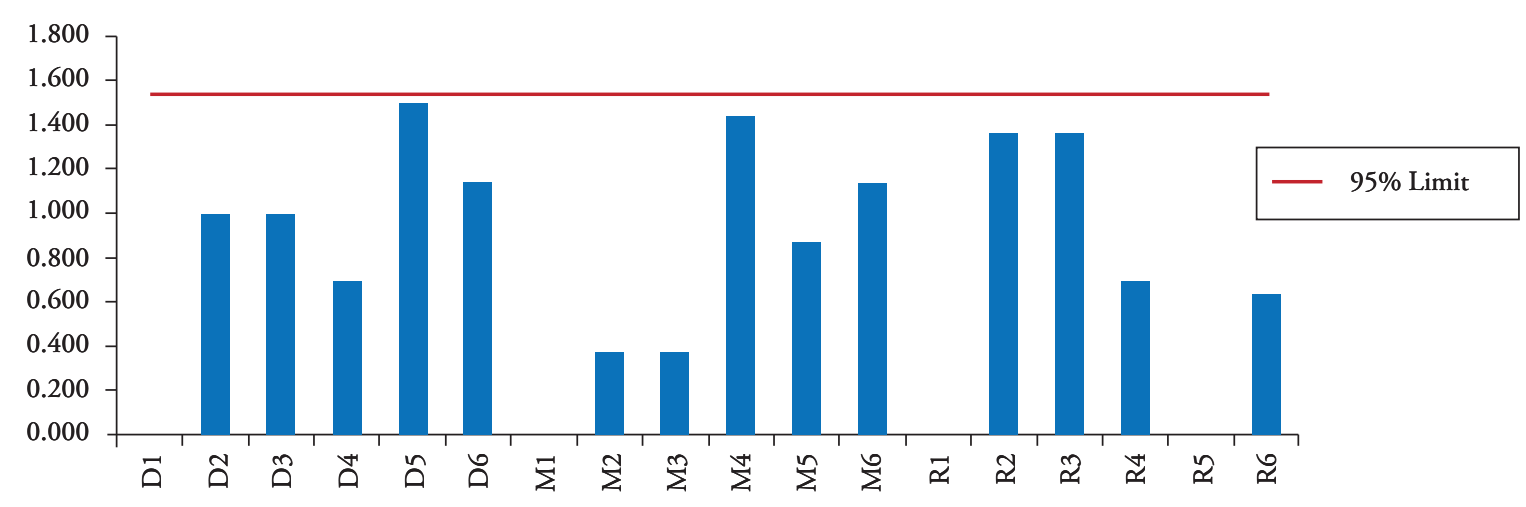

From the analysis of the results yielded during the confirmation of methods for caliper gauges of 150 $\mathrm{mm}$ measurement range, we may observe in the repeatability graphic that the measurement values are within the specifications for this process and a slight variation noted in the results from the three operators ( $\mathrm{M}$ and $\mathrm{R})$ is attributed to the operators, given that they are not constant among them.
Regarding the reproducibility analysis, it is observed that the three operators (D, M, and $\mathrm{R})$, present variability in the measurements; this may be attributed to the operator's skill when performing the measurement and it is derived from the equipment. These are within the specifications of the process.

Table 3. Measurement range up to $300 \mathrm{~mm}$, division of scale $0.01 \mathrm{~mm}$.

\begin{tabular}{|c|c|c|c|c|c|c|}
\hline \multirow{2}{*}{ Operator } & \multirow[b]{2}{*}{$\mathbf{0}$} & \multirow[b]{2}{*}{50} & \multicolumn{2}{|c|}{ Indications (mm) } & \multirow[b]{2}{*}{200} & \multirow[b]{2}{*}{300} \\
\hline & & & 100 & 150 & & \\
\hline \multirow{3}{*}{$\begin{array}{l}\text { Delwin } \\
\text { Velandia }\end{array}$} & 0.000 & 49.996 & 99.996 & 149.994 & 199.996 & 299.994 \\
\hline & 0.000 & 49.992 & 99.996 & 149.996 & 199.996 & 299.996 \\
\hline & 0.000 & 49.994 & 99.996 & 199.994 & 200.000 & 299.996 \\
\hline Mean & 0.0000 & 49.9940 & 99.9960 & 149.9947 & 199.9973 & 299.9953 \\
\hline Deviation & 0.000 & 0.002 & 0.000 & 0.001 & 0.002 & 0.001 \\
\hline $\mathbf{h}$ & 0.00000 & -0.00002 & 0.00000 & -0.00001 & 0.00000 & 0.00000 \\
\hline $\mathbf{k}$ & 0.00000 & 1.13389 & 0.00000 & 0.70711 & 1.04447 & 0.70711 \\
\hline \multirow{3}{*}{$\begin{array}{c}\text { Majer } \\
\text { Atequera }\end{array}$} & 0.000 & 49.998 & 99.994 & 149.996 & 199.996 & 299.994 \\
\hline & 0.000 & 49.994 & 99.996 & 149.998 & 199.996 & 299.998 \\
\hline & 0.000 & 49.996 & 99.998 & 149.996 & 200.000 & 299.998 \\
\hline
\end{tabular}




\begin{tabular}{|c|c|c|c|c|c|c|}
\hline Mean & 0.000 & 49.9960 & 99.9960 & 149.9967 & 199.9973 & 299.9967 \\
\hline Deviation & 0.000 & 0.002 & 0.002 & 0.001 & 0.002 & 0.002 \\
\hline h & 0.00000 & 0.00002 & 0.00000 & 0.00000 & 0.00000 & 0.00000 \\
\hline $\mathbf{k}$ & 0.00000 & 1.13389 & 1.50000 & 0.70711 & 1.04447 & 1.41421 \\
\hline \multirow{3}{*}{$\begin{array}{l}\text { Ronald } \\
\text { Argote }\end{array}$} & 0.000 & 49.996 & 99.998 & 149.998 & 199.996 & 299.996 \\
\hline & 0.000 & 49.996 & 99.996 & 149.998 & 199.998 & 299.998 \\
\hline & 0.000 & 49.994 & 99.998 & 149.994 & 200.000 & 299.998 \\
\hline Mean & 0.000 & 49.9960 & 99.9960 & 149.9967 & 199.9973 & 299.9967 \\
\hline Deviation & 0.000 & 0.002 & 0.002 & 0.001 & 0.002 & 0.002 \\
\hline h & 0.00000 & 0.00000 & 0.00001 & 0.00000 & 0.00000 & 0.00000 \\
\hline $\mathbf{k}$ & 0.00000 & 0.65465 & 0.86603 & 1.41421 & 0.90453 & 0.70711 \\
\hline
\end{tabular}

Fig. 6. Graph of h.

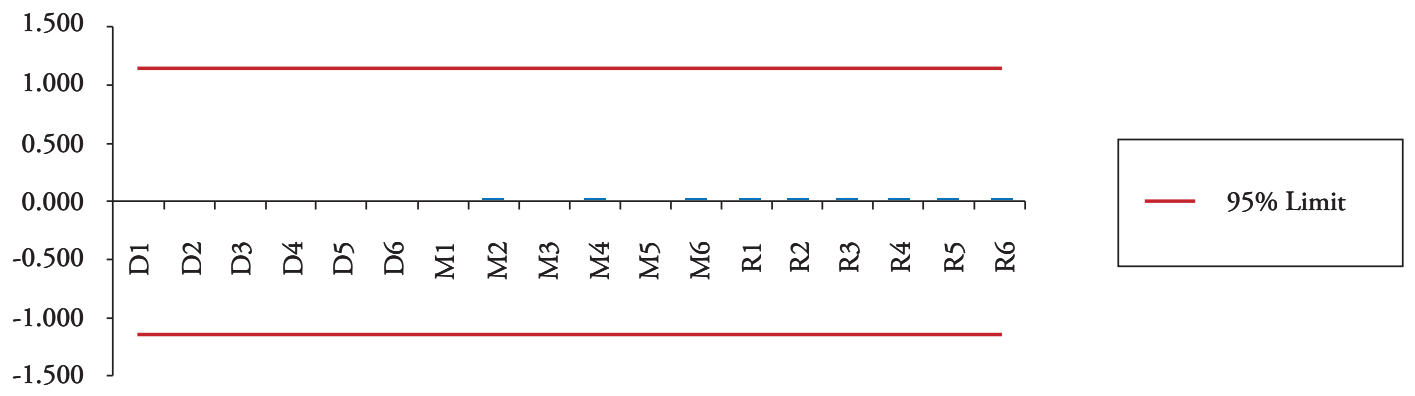

Fig. 7. Graph of k.

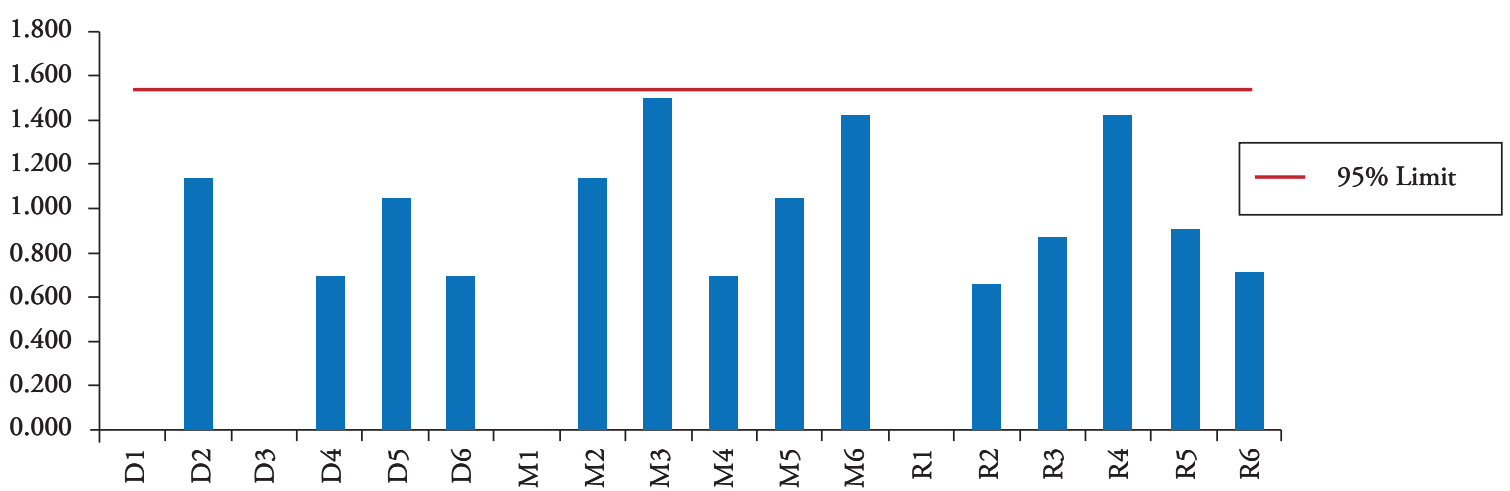

From the analysis of the results yielded during the confirmation of methods for caliper gauges of $300 \mathrm{~mm}$ measurement range, we may observe in the repeatability graphic that the measurement values are within the specifications for this process and a slight variation noted in the results from two operators ( $M$ and $R$ ) is attributed to the operators.
Regarding the reproducibility analysis, it is observed that the three operators (D, M, and $\mathrm{R})$, present variability in the measurements; this may be attributed to the operator's skill when performing the measurement and it is derived from the equipment. These are within the specifications of the process. 
Table 4. Measurement range up to $500 \mathrm{~mm}$, division of scale $0.01 \mathrm{~mm}$.

\begin{tabular}{|c|c|c|c|c|c|c|c|c|c|}
\hline \multirow{2}{*}{ Operator } & \multicolumn{9}{|c|}{ Indications $(\mathrm{mm})$} \\
\hline & $\mathbf{0}$ & 50 & 100 & 150 & 200 & 250 & 300 & 400 & 500 \\
\hline \multirow{3}{*}{$\begin{array}{l}\text { Delwin } \\
\text { Velandia }\end{array}$} & 0.000 & 49.986 & 99.988 & 149.990 & 199.992 & 249.996 & 299.992 & 399.998 & 499.998 \\
\hline & 0.000 & 49.988 & 99.994 & 149.992 & 199.994 & 249.994 & 299.994 & 399.998 & 500.000 \\
\hline & 0.000 & 49.988 & 99.992 & 149.990 & 199.990 & 249.996 & 299.992 & 400.000 & 499.998 \\
\hline Mean & 0.0000 & 49.9873 & 99.9913 & 149.9907 & 199.9920 & 249.9953 & 299.9927 & 399.9987 & 499.9987 \\
\hline Deviation & 0.000 & 0.001 & 0.003 & 0.001 & 0.002 & 0.001 & 0.001 & 0.001 & 0.001 \\
\hline $\mathbf{h}$ & 0.00000 & -0.00002 & 0.00001 & -0.00001 & 0.00000 & 0.00000 & -0.00001 & 0.00000 & 0.00000 \\
\hline $\mathbf{k}$ & 0.00000 & 0.77460 & 1.18322 & 1.22474 & 0.63960 & 1.22474 & 1.00000 & 0.70711 & 0.86603 \\
\hline \multirow{3}{*}{$\begin{array}{c}\text { Majer } \\
\text { Atequera }\end{array}$} & 0.000 & 49.990 & 99.998 & 149.992 & 199.994 & 249.996 & 299.996 & 399.998 & 499.998 \\
\hline & 0.000 & 49.990 & 99.990 & 149.990 & 199.990 & 249.996 & 299.994 & 399.998 & 500.000 \\
\hline & 0.000 & 49.998 & 99.988 & 149.992 & 199.988 & 249.996 & 299.994 & 399.994 & 499.996 \\
\hline Mean & 0.0000 & 49.9893 & 99.9887 & 149.9913 & 199.9907 & 249.9960 & 299.9947 & 399.9967 & 499.9980 \\
\hline Deviation & 0.000 & 0.001 & 0.001 & 0.001 & 0.003 & 0.000 & 0.001 & 0.002 & 0.002 \\
\hline $\mathbf{h}$ & 0.00000 & 0.00002 & -0.00002 & -0.00001 & 0.00000 & 0.00000 & 0.00000 & 0.00000 & 0.00000 \\
\hline $\mathbf{k}$ & 0.00000 & 0.77460 & 0.44721 & 1.22474 & 0.97701 & 0.00000 & 1.00000 & 1.41421 & 1.50000 \\
\hline \multirow{3}{*}{$\begin{array}{l}\text { Ronald } \\
\text { Argote }\end{array}$} & 0.000 & 49.986 & 99.988 & 149.996 & 199.996 & 249.998 & 299.996 & 399.996 & 499.998 \\
\hline & 0.000 & 49.998 & 99.990 & 149.996 & 199.988 & 249.996 & 299.994 & 399.998 & 499.998 \\
\hline & 0.000 & 49.990 & 99.994 & 149.996 & 199.992 & 249.998 & 299.996 & 399.996 & 499.998 \\
\hline Mean & 0.0000 & 49.9880 & 99.9907 & 149.9960 & 199.9920 & 249.9973 & 299.9953 & 399.9967 & 499.9980 \\
\hline Deviation & 0.000 & 0.002 & 0.003 & 0.000 & 0.004 & 0.001 & 0.001 & 0.001 & 0.000 \\
\hline h & 0.00000 & 0.00000 & 0.00000 & 0.00002 & 0.00000 & 0.00000 & 0.00000 & 0.00000 & 0.00000 \\
\hline $\mathbf{k}$ & 0.00000 & 1.34164 & 1.18322 & 0.00000 & 1.27920 & 1.22474 & 1.00000 & 0.70711 & 0.00000 \\
\hline
\end{tabular}

Fig. 8. Graph of h.

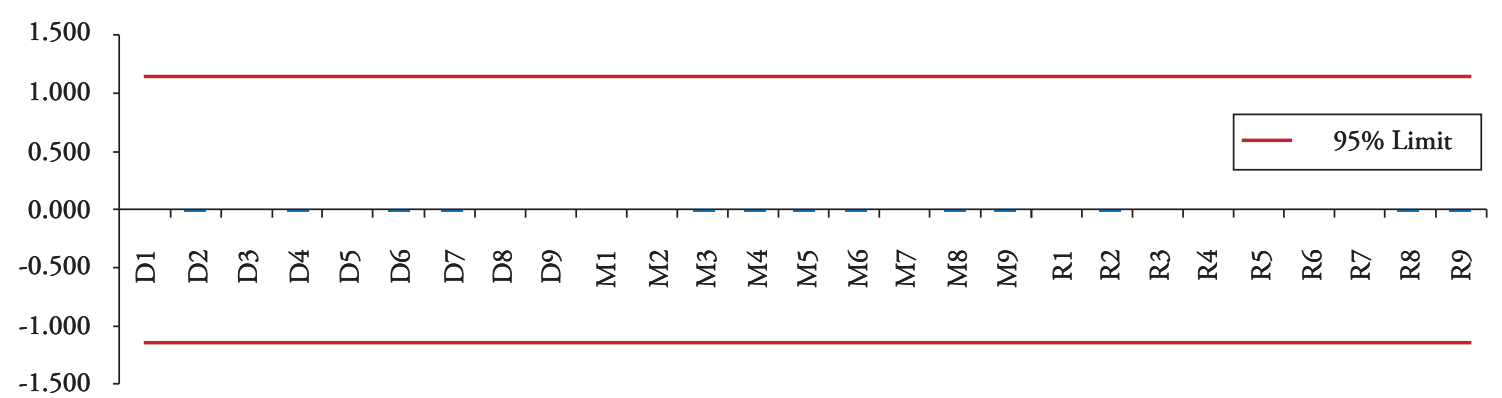

From the analysis of the results yielded during the confirmation of methods for caliper gauges of 500 $\mathrm{mm}$ measurement range, we may observe in the repeatability graphic that the measurement values are within the specifications for this process and a slight variation noted in the results from the three operators (D, M, and $\mathrm{R})$ is attributed to the operators.
Regarding the reproducibility analysis, it is observed that the three operators (D, M, and $\mathrm{R})$, present variability in the measurements; this may be attributed to the operator's skill when performing the measurement and it is derived from the equipment. These are within the specifications of the process. 


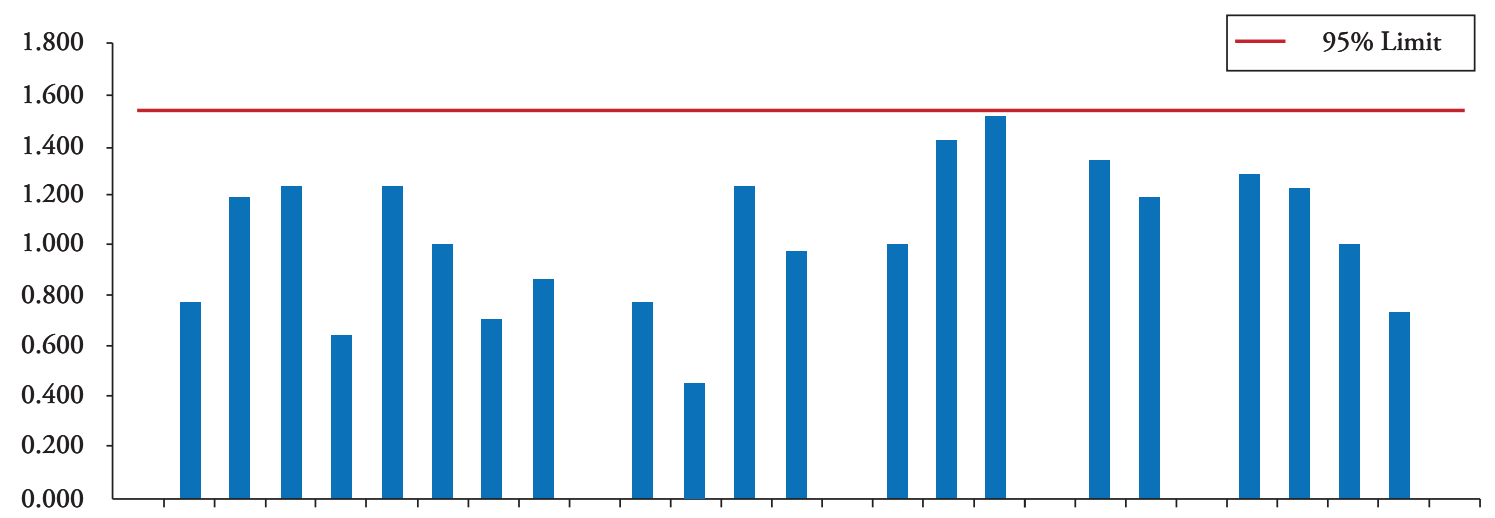

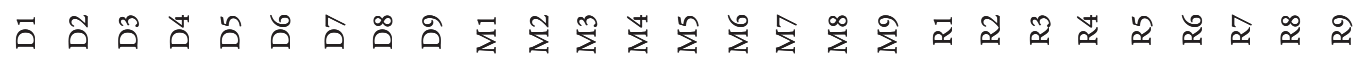

Table 5. Measurement range up to $900 \mathrm{~mm}$, division of scale $0.02 \mathrm{~mm}$.

\begin{tabular}{|c|c|c|c|c|c|c|c|c|c|}
\hline \multirow{2}{*}{ Operator } & \multicolumn{9}{|c|}{ Indications (mm) } \\
\hline & $\mathbf{0}$ & 50 & 100 & 200 & 300 & 400 & 500 & 750 & 900 \\
\hline \multirow{3}{*}{$\begin{array}{l}\text { Delwin } \\
\text { Velandia }\end{array}$} & 0.000 & 50.000 & 100.000 & 200.000 & 300.000 & 400.000 & 500.000 & 750.000 & 900.000 \\
\hline & 0.000 & 50.000 & 100.000 & 200.000 & 300.000 & 400.000 & 500.000 & 750.000 & 900.000 \\
\hline & 0.000 & 50.000 & 100.000 & 200.000 & 300.000 & 400.000 & 500.000 & 750.004 & 900.004 \\
\hline Mean & 0.0000 & 50.0000 & 100.0000 & 200.0000 & 300.0000 & 400.0000 & 500.0000 & 750.0013 & 900.0013 \\
\hline Deviation & 0.000 & 0.000 & 0.000 & 0.000 & 0.000 & 0.000 & 0.000 & 0.002 & 0.002 \\
\hline $\mathbf{h}$ & 0.00000 & 0.00000 & 0.00000 & 0.00000 & 0.00000 & 0.00000 & 0.00000 & 0.00000 & 0.00000 \\
\hline $\mathbf{k}$ & 0.00000 & 0.00000 & 0.00000 & 0.00000 & 0.00000 & 0.00000 & 0.00000 & 1.22474 & 1.00000 \\
\hline \multirow{3}{*}{$\begin{array}{c}\text { Majer } \\
\text { Atequera }\end{array}$} & 0.000 & 50.000 & 100.000 & 200.000 & 300.000 & 400.000 & 500.000 & 750.000 & 900.000 \\
\hline & 0.000 & 50.000 & 100.000 & 200.000 & 300.000 & 400.000 & 500.000 & 750.000 & 900.004 \\
\hline & 0.000 & 50.000 & 100.000 & 200.000 & 300.000 & 400.000 & 500.000 & 750.000 & 900.000 \\
\hline Mean & 0.0000 & 50.0000 & 100.0000 & 200.0000 & 300.0000 & 400.0000 & 500.0000 & 750.0000 & 900.0013 \\
\hline Deviation & 0.000 & 0.000 & 0.000 & 0.000 & 0.000 & 0.000 & 0.000 & 0.002 & 0.002 \\
\hline h & 0.00000 & 0.00000 & 0.00000 & 0.00000 & 0.00000 & 0.00000 & 0.00000 & 0.00000 & 0.00000 \\
\hline $\mathbf{k}$ & 0.00000 & 0.00000 & 0.00000 & 0.00000 & 0.00000 & 0.00000 & 0.00000 & 0.00000 & 1.00000 \\
\hline \multirow{3}{*}{$\begin{array}{l}\text { Ronald } \\
\text { Argote }\end{array}$} & 0.000 & 50.000 & 100.000 & 200.000 & 300.000 & 400.000 & 500.000 & 750.000 & 900.004 \\
\hline & 0.000 & 50.000 & 100.000 & 200.000 & 300.000 & 400.000 & 500.000 & 750.004 & 900.000 \\
\hline & 0.000 & 50.000 & 100.000 & 200.000 & 300.000 & 400.000 & 500.000 & 750.000 & 900.000 \\
\hline Mean & 0.0000 & 50.0000 & 100.0000 & 200.0000 & 300.0000 & 400.0000 & 500.0000 & 750.0013 & 900.0013 \\
\hline Deviation & 0.000 & 0.000 & 0.000 & 0.000 & 0.000 & 0.000 & 0.000 & 0.002 & 0.002 \\
\hline h & 0.00000 & 0.00000 & 0.00000 & 0.00000 & 0.00000 & 0.00000 & 0.00000 & 0.00000 & 0.00000 \\
\hline $\mathbf{k}$ & 0.00000 & 0.00000 & 0.00000 & 0.00000 & 0.00000 & 0.00000 & 0.00000 & 1.22474 & 1.00000 \\
\hline
\end{tabular}

From the analysis of the results yielded during the confirmation of methods for caliper gauges of 900 $\mathrm{mm}$ measurement range, we may observe in the repeatability graphic that the measurement values are within the specifications for this process and a slight variation noted in the results from the operator (M) is attributed to the operator.

Regarding the reproducibility analysis, it is noted that the three operators (D, M, and R) present 
constant variations in some specific points in the equipment. These are within the specifications the measurement; this may be attributed to the of the process.

measurement instrument and to that derived from

Fig. 10. Graph of h.

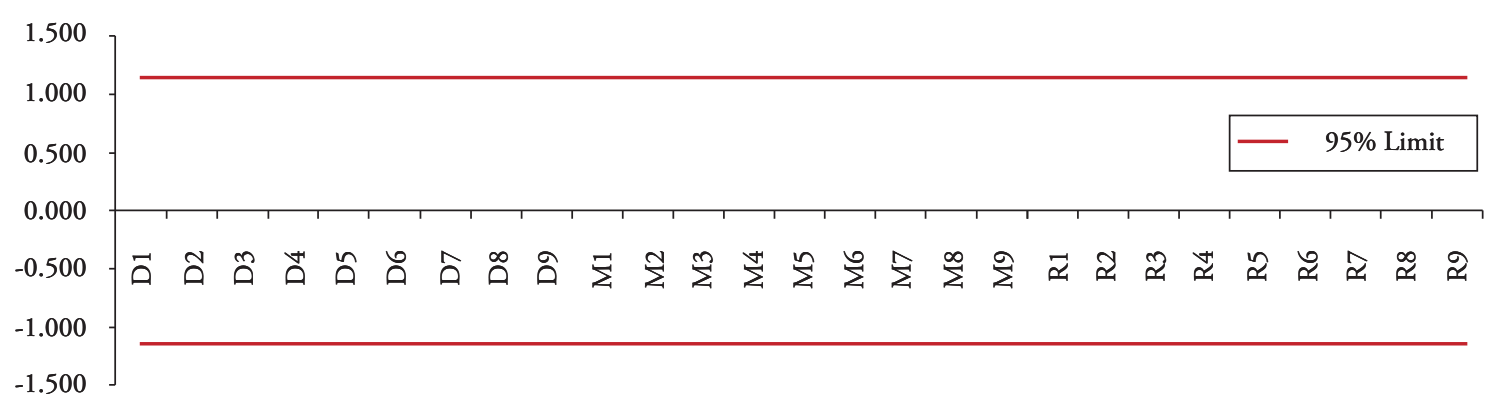

Fig. 11. Graph of k.

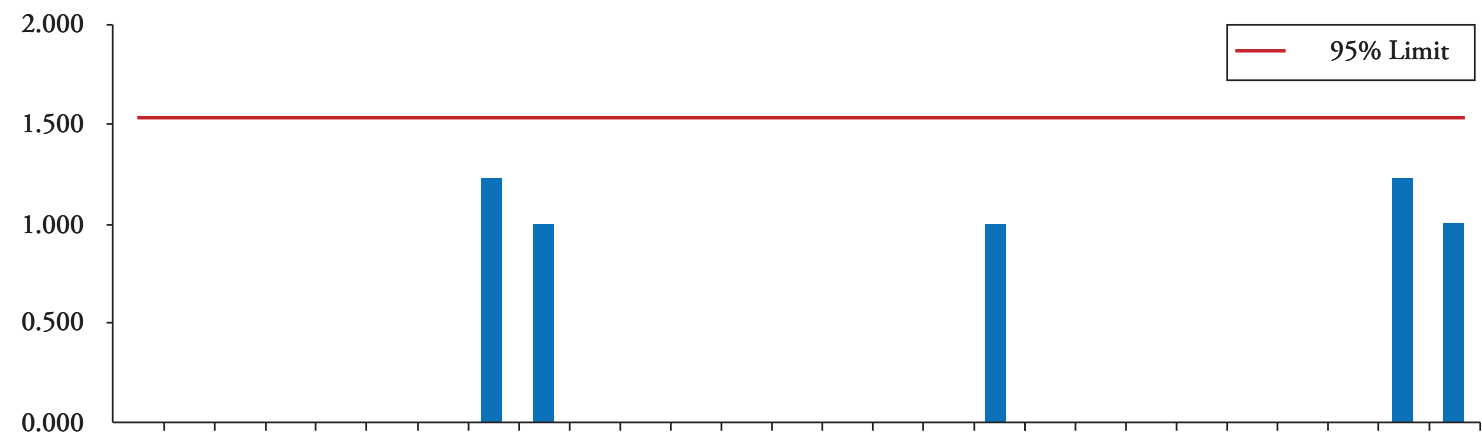

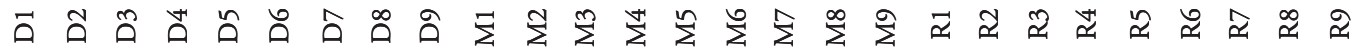

\section{Estimation of uncertainty}

Estimation of uncertainty during each calibration was determined by following the guidelines from the GTC 51:1997 guide "Guide for the expression of uncertainty in measurements".

The uncertainties estimated for each measurement interval are shown in the following tables:

a) Interval up to $150 \mathrm{~mm}$, division of scale $0.01 \mathrm{~mm}$

Table 6. Calliper gauge (0-150 mm).

\begin{tabular}{|c|c|c|c|}
\hline Person selected & Calibration No. & $\mathrm{U} \exp \left({ }_{\mu} \mathbf{m}\right)$ & CMC \\
\hline D & 1 & 8.7 & \\
\hline $\mathrm{D}$ & 2 & 7.7 & 7.7 \\
\hline $\mathrm{D}$ & 3 & 7.7 & \\
\hline
\end{tabular}

\begin{tabular}{|c|c|c|}
\hline $\mathrm{M}$ & 1 & 7.7 \\
\hline M & 2 & 9.6 \\
\hline M & 3 & 10.0 \\
\hline $\mathrm{R}$ & 1 & 8.7 \\
\hline $\mathrm{R}$ & 2 & 7.7 \\
\hline $\mathrm{R}$ & 3 & 7.7 \\
\hline
\end{tabular}

b) Interval up to $300 \mathrm{~mm}$, division of scale $0.01 \mathrm{~mm}$

Table 7. Calliper gauge $(0-300 \mathrm{~mm})$.

\begin{tabular}{|c|c|c|c|}
\hline Person selected & Calibration No. & $U \exp \left({ }_{\mu} \mathbf{m}\right)$ & CMC \\
\hline $\mathrm{D}$ & 1 & 7.9 & \multirow{6}{*}{7.9} \\
\hline $\mathrm{D}$ & 2 & 7.9 & \\
\hline $\mathrm{D}$ & 3 & 8.9 & \\
\hline M & 1 & 7.9 & \\
\hline M & 2 & 7.9 & \\
\hline $\mathrm{M}$ & 3 & 8.9 & \\
\hline
\end{tabular}




\begin{tabular}{|c|c|c|}
\hline $\mathrm{R}$ & 1 & 7.9 \\
\hline $\mathrm{R}$ & 2 & 7.9 \\
\hline $\mathrm{R}$ & 3 & 8.9 \\
\hline
\end{tabular}

c) Interval up to $500 \mathrm{~mm}$, division of scale $0.01 \mathrm{~mm}$

Table 8. Calliper gauge (0-500 mm).

\begin{tabular}{|c|c|c|c|}
\hline Person selected & Calibration No. & $\mathrm{U} \exp \left({ }_{\mu} \mathbf{m}\right)$ & CMC \\
\hline $\mathrm{D}$ & 1 & 11.0 & \\
\hline $\mathrm{D}$ & 2 & 9.9 & \\
\hline D & 3 & 12.1 & \\
\hline M & 1 & 9.9 & \\
\hline M & 2 & 9.1 & 8.1 \\
\hline M & 3 & 9.9 & \\
\hline $\mathrm{R}$ & 1 & 9.9 & \\
\hline $\mathrm{R}$ & 2 & 9.1 & \\
\hline $\mathrm{R}$ & 3 & 8.1 & \\
\hline
\end{tabular}

d) Interval up to $900 \mathrm{~mm}$, division of scale $0.02 \mathrm{~mm}$

Table 9. Calliper gauge (0-900 mm).

\begin{tabular}{|c|c|c|c|}
\hline Person selected & Calibration No. & $U \exp \left({ }_{\mu} m\right)$ & CMC \\
\hline $\mathrm{D}$ & 1 & 12.1 & \\
\hline $\mathrm{D}$ & 2 & 12.1 & \\
\hline $\mathrm{D}$ & 3 & 14.5 & \\
\hline M & 1 & 14.5 & \\
\hline M & 2 & 12.1 & 12.1 \\
\hline M & 3 & 12.1 & \\
\hline $\mathrm{R}$ & 1 & 14.5 & \\
\hline $\mathrm{R}$ & 2 & 12.1 & \\
\hline $\mathrm{R}$ & 3 & 12.1 & \\
\hline
\end{tabular}

According to the results obtained, we have:

a) Interval up to $150 \mathrm{~mm}$, division of scale $0.01 \mathrm{~mm}$. $\mathrm{CMC}=7.7 \mu \mathrm{m}$

b) Interval up to $300 \mathrm{~mm}$, division of scale $0.01 \mathrm{~mm}$. $\mathrm{CMC}=7.9 \mu \mathrm{m}$

c) Interval up to $500 \mathrm{~mm}$, division of scale $0.01 \mathrm{~mm}$. $\mathrm{CMC}=8.1 \mu \mathrm{m}$ d) Interval up to $900 \mathrm{~mm}$, division of scale $0.02 \mathrm{~mm}$. $\mathrm{CMC}=12.1 \mu \mathrm{m}$

\section{Conclusions}

It may be determined through the confirmation method that the repeatability of the measurements presented by the three operators is within the specifications for each of their measurement ranges; operator $\mathrm{D}$ presents a variation per equipment; this may be attributed to the instrument.

It may be determined through the confirmation method that the reproducibility of the measurements presented by the three operators are within specifications for each of their measurement ranges; the three graphics show that the operators presented constant values, which is due to the instrument and method used.

According to the results obtained and exposed in this report, the method remains confirmed. Las CMCs reported clearly show the precision COTECMAR'S metrology laboratory is offering to the different areas performing measurements in the Corporation. This methodology will allow us to reevaluate the corporate measurement processes and make decisions that lead to continuous improvement of production processes.

\section{References}

http://www.inocar.mil.ec/web/images/ lotaip/2015/literal_a/base_legal/A._ Convenio_internacional_solas_1974.pdf. Instituto Oceanográfico de la Armada INOCAR. Ecuador. 2015-05-31.

http://www.inocar.mil.ec/web/images/ lotaip/2015/literal_a/base_legal/A._ Convenio_internacional_solas_1974.pdf. Instituto Oceanográfico de la Armada INOCAR. Ecuador. 2015-05-31.

https://www.dimar.mil.co/content/conveniointernacional-sobre-la-seguridad-de-lavida-humana-en-el-mar. Dirección General 
Marítima, Autoridad Marítima Colombiana. http://www.metas.com.mx/guiametas/La-Guia2015-05-31. MetAs-07-09-proceso-de-medicion.pdf. MetAs \& Metrólogos Asociados. La Guía MetAs. September 2007.

http://www.semana.com/especiales/articulo/ potencia-naval/47869-3. Revista Semana. 2001-11-05.

INTERNATIONAL METROLOGY VOCABULARY. VIM-3rd edition (2012).

http://www.cotecmar.com/conozcanos.html. Portal COTECMAR. 2015-05-31.

http://www.metas.com.mx/guiametas/La-GuiaMetAs-07-09-proceso-de-medicion.pdf.

https://fernandoveyretou.files.wordpress. com/2011/06/validacion-y-confirmacionde-metodos26.pdf. Ingeniería en Calidad - Fernando Veyretou. Temas de Calidad. Laboratorio. 2011-06-10. MetAs \& Metrólogos Asociados. La Guía MetAs. September 2007.

INTERNATIONAL METROLOGY VOCABULARY. VIM-3rd edition (2012). 